\title{
Proneotermes macondianus, a new drywood termite from Colombia and expanded distribution of Proneotermes in the Neotropics (Isoptera, Kalotermitidae)
}

\author{
Robin Casalla ${ }^{1,2}$, Rudolf H. Scheffrahn³, Judith Korb' \\ I Universität Freiburg. Evolutionary Biology \& Ecology. Hauptstrasse 1, Freiburg 79104 Germany 2 Universi- \\ dad del Norte. Departamento de Química y Biología. Kilómetro 5 Antigua vía Puerto Colombia, Barranquilla \\ Colombia 3 University of Florida. Fort Lauderdale Research \& Education Center, 3205 College Avenue Davie, \\ Florida 33314 United States \\ Corresponding author: Robin Casalla (casallar@uninorte.edu.co) \\ Academic editor: E. Cancello | Received 26 June 2016 | Accepted 23 September 2016 | Published 11 October 2016 \\ http://zoobank.org/5E560CB9-4AE3-4E8A-ACBD-B8E8DEC0D799 \\ Citation: Casalla R, Scheffrahn RH, Korb J (2016) Proneotermes macondianus, a new drywood termite from Colombia \\ and expanded distribution of Proneotermes in the Neotropics (Isoptera, Kalotermitidae). ZooKeys 623: 43-60. doi: \\ $10.3897 /$ zookeys.623.9677
}

\begin{abstract}
After more than one hundred years, a new drywood termite of the genus Proneotermes is described from the tropical dry forest in the Caribbean coast of Colombia. Morphological and genetic analyses are given for Proneotermes macondianus sp. $\mathbf{n}$. This termite occurs in tropical dry forests in small colonies inside thin branches of dry wood. The soldier of $P$. macondianus is smaller and the genal horns are angled outward compared to the other two described Proneotermes species. The imago wings are unusually short and wide. Genetic analyses for COII, 12S, and $16 \mathrm{~S}$ genes show less than three percent difference between sample localities of $P$. macondianus. Intergeneric comparison with selected kalotermitid genera indicates that Bifiditermes is the most closely related genus of those sequenced. New morphological descriptions and morphometric measurements of Proneotermes latifrons based on the soldier caste are also included. Neotropical locality records for $P$. latifrons and Proneotermes perezi are provided.
\end{abstract}

\section{Keywords}

Northern Colombian coast, Proneotermes keys, Proneotermes macondianus sp. n., tropical dry forest

Copyright Robin Casalla et al. This is an open access article distributed under the terms of the Creative Commons Attribution License (CC BY 4.0), which permits unrestricted use, distribution, and reproduction in any medium, provided the original author and source are credited. 


\section{Introduction}

Colombia's diverse ecoregions harbour high termite diversity (Morrone 2006, Robledo et al. 2014). Vargas-Nińo et al. (2005) and Krishna et al. (2013) together report 29 genera of higher termites (Termitidae). Ten additional generic termitid records, mostly Apicotermitinae, have been collected in Colombia (Scheffrahn unpubl. data). Among the Kalotermitidae, six genera (Calcaritermes, Comatermes, Cryptotermes, Glyptotermes, Incisitermes, and Neotermes) are known from Colombia (Krishna et al. 2013, Rodríguez et al. 2012). The tropical dry forest of Colombia's Caribbean coast has recently revealed a new species and two new records of Cryptotermes (Casalla et al. 2016).

For more than a century, the genus Proneotermes was represented by two species, Proneotermes latifrons (Silvestri, 1901) from Venezuela and Proneotermes perezi (Holmgren 1911) from Costa Rica (Krishna et al. 2013). DNA barcoding is a molecular tool used to identify and to track the evolutionary biology of species (Thompson et al. 2000, Inward et al. 2007, Hausberger et al. 2011, Bourguignon et al. 2014). Evolutionary analyses within the Kalotermitidae are incomplete and limited to some genera (Legendre et al. 2008). Hence a comparative genetic analysis can help to determine relationships for Proneotermes.

In this paper, a new species of Proneotermes is described, $P$. macondianus. In addition, new morphological descriptions are included for the soldier of $P$. latifrons and new soldier measurements provided for $P$. perezi as well as new locality records for Proneotermes in the Neotropics.

\section{Methods}

\section{Study sites and sampling}

Three study sites in a tropical dry forest near Colombia's Caribbean coast were selected and surveyed during July 2014 and August 2015 (Fig. 1). The area of "Los Primates" in the mountains of municipality of Colosó, Sucre and the "El Ceibal" in Santa Catalina Bolívar, are part of the system of protected areas, while the "El Parque Tayrona" is a Natural National Park of Colombia in Santa Marta, Magdalena. These forests are one of the best preserved areas of tropical dry forest in the Colombian Caribbean coast (Instituto de Investigación Alexander von Humboldt 2014). Samples of a new Proneotermes were collected in those places using a standardized sampling protocol (Jones and Eggleton 2000, Hausberger and Korb 2015) that included collecting small dry branches and dry wood on the ground. Specimens were preserved in 100\% ethanol for DNA analysis and $80 \%$ ethanol for museum curation.

\section{Identification}

Morphometrics for $P$. latifrons and $P$. perezi were obtained from specimens from the University of Florida Termite Collection, Davie, Florida. Specimens of P. macondianus 


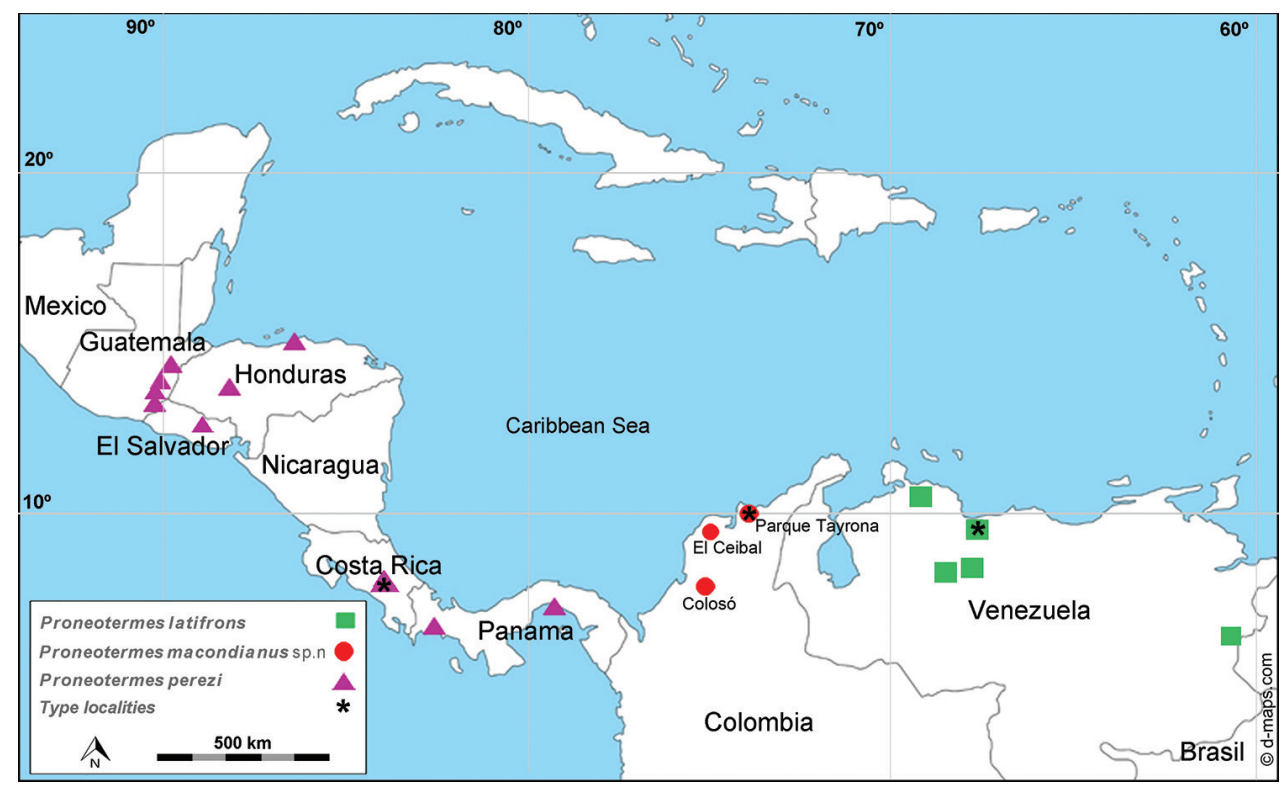

Figure I. Sampling localities for Proneotermes macondianus sp. $\mathrm{n}$ in Colombia and new records from University of Florida collection for P. latifrons and P. perezi.

sp. n. were also sequenced for genetic comparisons. Total DNA was extracted from pseudergates and alate imagoes heads using the CTAB protocol (Doyle and Doyle 1987). PCRs and sequencing were performed for mitochondrial gene fragments from cytochrome oxidase II (COII) ( $-740 \mathrm{bp}), 12 \mathrm{~S}$ rDNA ( $-385 \mathrm{bp})$, and $16 \mathrm{~S}$ rDNA $(-480$ bp) as described in Hausberger et al. (2011).

For the three different haplotypes of $P$. macondianus from the northern Colombian coast (separated $-200 \mathrm{~km}$ from each other), we used the combined COII, $12 \mathrm{~S}$, and $16 \mathrm{~S}$ nucleotide sequences to calculate the $p$-distance $\left(3000^{\text {th }}\right.$ Bootstrap replications, Gamma Distributed and Transitions + Transversions).

Due to limited availability of mitochondrial gene sequences for Kalotermitidae in National Center for Biotechnology Information (NCBI), we restricted our phylogenetic analysis to only the COII fragment. Twelve genera of Kalotermitidae and Cryptocercus punctulatus as the outgroup were used (Table 1). Sequences were aligned with MUSCLE alignment algorithm as implemented in MEGA 7.0 with default settings (Kumar et al. 2016). A phylogenetic tree was inferred based in a Bayesian approach using MrBayes 3.2.1. (Ronquist and Huelsenbeck and 2003) (10 7 generations with every $1000^{\text {th }}$ tree sampled, using the default of four chains). After checking for convergence, we discarded $50 \%$ as burn-in. The resultant tree was visualized using FigTree 1.4 .2 (http://tree.bio.ed.ac.uk/software/figtree/). Additionally, MEGA 7.0 was also employed (Kumar et al. 2016) to calculate $p$-distances (as described above) between all species using the COII fragment. All positions containing gaps and missing data were eliminated. 
Table I. GenBank accession numbers for COII, 12S and 16S sequences.

\begin{tabular}{|c|c|c|c|}
\hline Species & Accession COII & GenBank Accession 12S & Accession 16S \\
\hline Cryptocercus punctulatus & DQ007637.1 & - & - \\
\hline Bifiditermes improbus & AF189079.1 & - & - \\
\hline Bifiditermes improbus & AF189080.1 & - & - \\
\hline Calcaritermes temnocephalus & EU253877.1 & - & - \\
\hline Comatermes perfectus & EU253878.1 & - & - \\
\hline Cryptotermes cavifrons & FN377810.1 & - & - \\
\hline Cryptotermes longicollis & FN377806.1 & - & - \\
\hline Epicalotermes mkuzii & DQ442125.1 & - & - \\
\hline Glyptotermes brevicornis & AF189096.1 & - & - \\
\hline Glyptotermes iridipenis & AF189096.2 & - & - \\
\hline Glyptotermes satsumensis & KP026257.1 & - & - \\
\hline Incisitermes immigrans & AB109542.1 & - & - \\
\hline Incisitermes tabogae & EU253880.1 & - & - \\
\hline Kalotermes flavicollis & DQ442147.1 & - & - \\
\hline Marginitermes sp. & KJ907844.1 & - & - \\
\hline Neotermes castaneus & HQ215844.1 & - & - \\
\hline Neotermes holmgreni & EU253882.1 & - & - \\
\hline Neotermes insularis & AF189105.1 & - & - \\
\hline Postelectrotermes amplus & DQ442147.1 & - & - \\
\hline Postelectrotermes howa & EU253883.1 & - & - \\
\hline Procryptotermes leewardensis & EU253884.1 & - & - \\
\hline Proneotermes macondianus $C E^{*}$ & KX267096 & KX267094 & KX267091 \\
\hline Proneotermes macondianus $\mathrm{CO}^{* *}$ & KX267097 & KX267093 & KX267090 \\
\hline Proneotermes macondianus $P T^{* * *}$ & KX267098 & KX267095 & KX267092 \\
\hline
\end{tabular}

Samples localites: $\mathrm{CE}^{*}=$ El Ceibal (Santa Catalina, Bolívar), CO** = Los Primates (Colosó, Sucre), PT*** = Parque Tayrona (Santa Marta, Magdalena)

\section{Imaging and measurements}

Specimens were suspended in Hand Sanitizer and images were taken with a Leica MC205 C stereomicroscope coupled to a Leica MC190 HD digital camera. The software Helicon Focus was used to stack pictures. Measurements were done following Roonwal (1969). Wings and mandibles were detached and mounted onto slides and edited with Photoshop CS5 V12.0.

\section{Deposit}

Voucher specimens are held at the University of Freiburg, Germany. The holotype soldier and paratypes of Proneotermes macondianus will be deposited at the Natural History Museum of the Alexander von Humboldt Institute of Bogotá (MIAvH) and a paratype soldier at the collection of the American Museum of Natural History, New 
York. De-alates (wings detached) and pseudergates of $P$. macondianus will be part of the collection of the Department of Chemistry and Biology at the Universidad del Norte, Barranquilla, Colombia.

\section{Results}

\section{Family Kalotermitidae Froggatt, 1897 \\ Genus Proneotermes Holmgren, 1911}

\section{Proneotermes macondianus sp. $\mathrm{n}$. http://zoobank.org/AB0F7282-534A-448D-AC80-86E697A18E9E}

Diagnosis. The Proneotermes macondianus soldier is smaller and the head capsule lighter than those of $P$. latifrons and $P$. perezi. In $P$. macondianus, the lateral margins of the genal horns angle outward from the sides of the head capsule while, in the other two species, the lateral margins of the genal horns remain in line with the head capsule. The mandibular humps of $P$. macondianus are more pronounced and rounded than in $P$. latifrons and $P$. perezi. Both $P$. latifrons and $P$. perezi have more robust rugosity on the frons than $P$. macondianus. The imago of $P$. macondianus is smaller and has much shorter, wider, darker, and more punctate wings than that of $P$. perezi.

Description. Imago (Figs 2, 3A, Table 2). Head dorsal view: yellowish weakly trapezoidal, eyes moderately protruding and small, diameter $0.30 \mathrm{~mm}$ (Fig. 2A-B). Ocellus oval and almost touching eye (Fig. 2B). Antenna with 15 articles. Pronotum broader than head (Fig. 2A). Forewing with all major veins running parallel; subcosta running from suture to costal margin about $1 / 5$ length of wing, radius to $1 / 3$ wing length, radial sector with 4-6 branches, media less sclerotized than anterior veins, and cubitus unsclerotized Wings brownish, especially near scale suture, membrane nodular; unusually wide and relatively short. Fore wing with a very long suture line margin; scale much darker that body pigmentation (Fig. 3A). Measurements are reported in Table 2.

Soldier (Figs 3B, 4, Table 3). Head in dorsal view with postclypeus almost black, grading to ferruginous orange near frontal flange, and yellow at occiput (Fig. 4A). Dorsal view with head elongate and sides parallel, frons wide and shallow and faint frontal flange (Fig. 4B). Eye spots distinct, unpigmented. Mandibles completely black (Fig. 3B, 4A-C). Pronotum yellowish with anterior borders brown. Frons angles below vertex approx. $43^{\circ}$. Rugosity vestigial on the frons or vertex regions of the head. Frontal horns robust and project towards the front (Fig. 4A). Genal horns prominent in dorsal view, angled antero-laterally about $45^{\circ}$. Mandible tips bend about $60-65^{\circ}$ from longitudinal axis of mandibular blade, prominent dentition, with rounded and pronounced mandibular humps: left hump larger than right (Figs 3B, 4A). Postmentum somewhat constricted in middle, as cup-shaped (Fig. 4C). Third antennal article enlarged and sclerotized, formula $2<3>4=5=6$ and 11 articles. Pronotum as broad as 

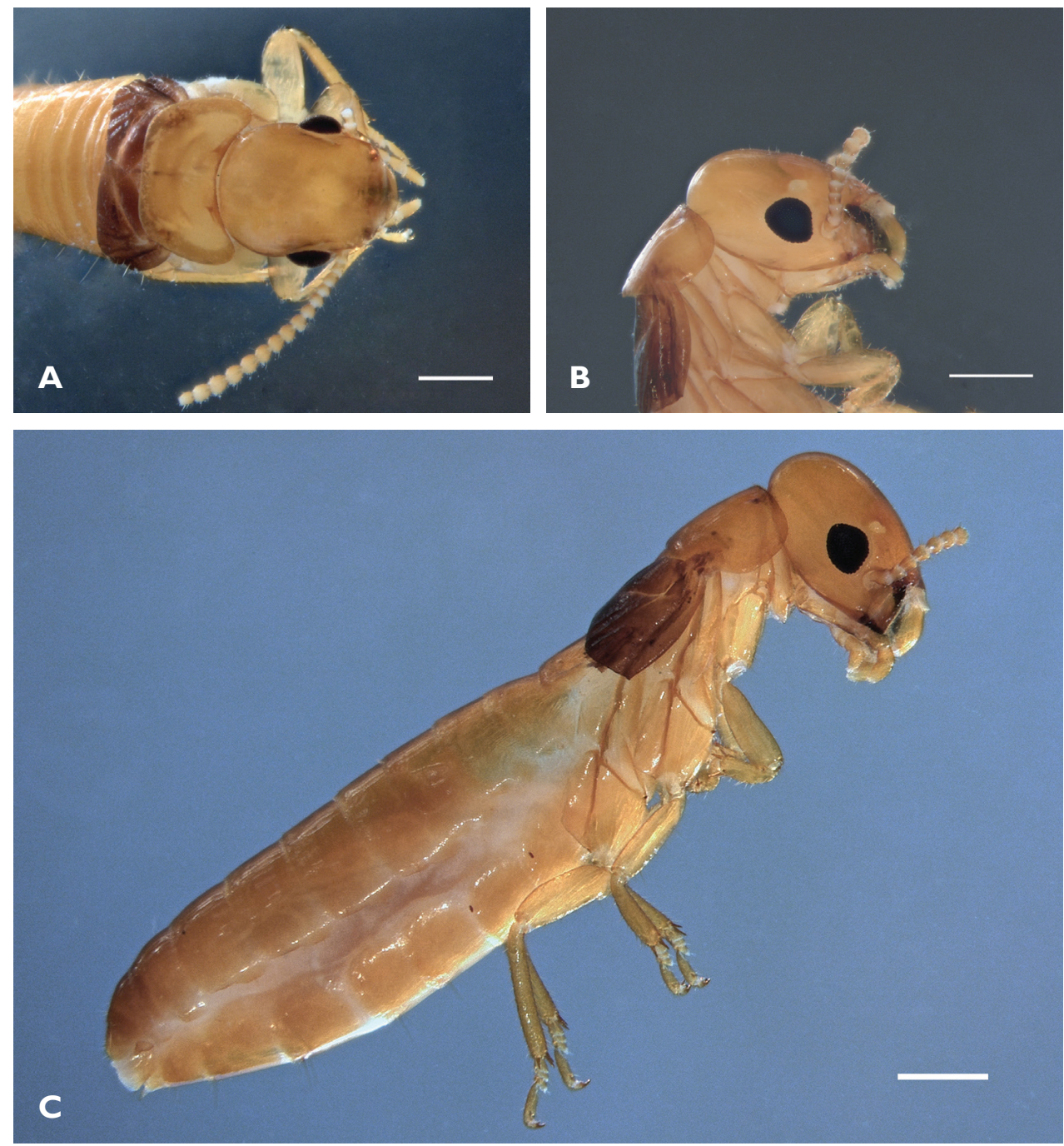

Figure 2. Proneotermes macondianus sp. n. imago: A Head in dorsal B lateral, and $\mathbf{C}$ whole body in lateral. Scale bars: $0.5 \mathrm{~mm}$.

head; anterior emarginate. Measurements are reported in Table 3. The soldiers from the Tayrona National Park (Santa Marta, Magdalena) showed slightly darker coloration than those from the samples sites at El Ceibal (Santa Catalina, Bolívar) and Colosó (Colosó, Sucre).

Genetic analysis. The COII, 12S, and $16 \mathrm{~S}$ sequences obtained in this study are deposited in GenBank under accession numbers KX267090-KX267098 (Table 1). The combined COII, 12S, and $16 \mathrm{~S}$ nucleotide data of three different haplotypes of P. macondianus from the northern Colombian coast (separated $-200 \mathrm{~km}$ from each other) revealed genetic distances of about 2.5\% (p-distance, SE 0.004; 38bp / 1488bp) 

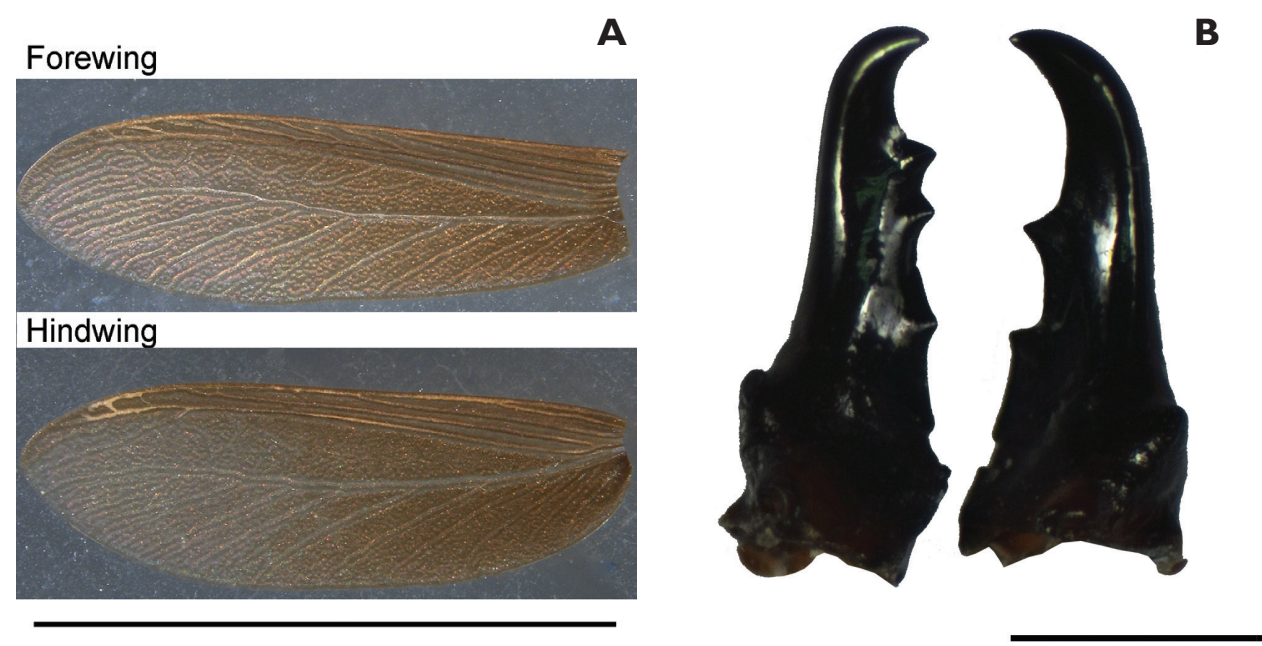

Figure 3. Proneotermes macondianus sp. n. Alate: A fore- and hindwing, scale bar: $5 \mathrm{~mm}$. Soldier: B mandibles, scale bar: $1 \mathrm{~mm}$.

Table 2. Morphometrical measurements for P. macondianus sp. n. imagoes.

\begin{tabular}{c|l|c|c|c}
\hline No. & \multicolumn{1}{|c|}{ Measurements in mm $(\mathbf{n}=\mathbf{1 0})}$. & Mean & SD & Range \\
\hline 1 & Head length with labrum & 1.28 & 0.06 & $1.18-1.35$ \\
\hline 2 & Head length to postclypeus & 1.14 & 0.04 & $1.06-1.19$ \\
\hline 3 & Head width, maximum at eyes & 0.95 & 0.04 & $0.88-1.01$ \\
\hline 4 & Eye diameter, maximum & 0.30 & 0.02 & $0.26-0.31$ \\
\hline 5 & Eye to head base, minimum & 0.14 & 0.01 & $0.12-0.16$ \\
\hline 6 & Ocellus diameter & 0.11 & 0.02 & $0.09-0.13$ \\
\hline 7 & Pronotum maximum width & 1.05 & 0.05 & $0.94-1.13$ \\
\hline 8 & Pronotum maximum length & 0.66 & 0.02 & $0.63-0.69$ \\
\hline 9 & Total length without wings & 5.45 & 0.33 & $5.04-5.87$ \\
\hline 10 & Total length with wings $(\mathrm{n}=1)$ & 7.52 & - & - \\
\hline 11 & Fore wing length to suture $(\mathrm{n}=1)$ & 5.24 & - & - \\
\hline 12 & Fore wing maximum width $(\mathrm{n}=1)$ & 1.63 & - & - \\
\hline 13 & No. antennal articulations & 9 & 2.4 & $7-15$ \\
\hline
\end{tabular}

(Table 4). Our Bayesian phylogenetic tree shows more than 74\% Bayesian Posterior Probability (BPP) support for all nodes (Fig. 5). The COII based tree suggests that Proneotermes is the sister taxon to a cluster consisting of [(Marginitermes + Epicalotermes) + Bifiditermes $]+[($ Cryptotermes + Procrypotermes $)+$ Incisitermes $]$. Since Kalotermitid sequences for $12 S$ and $16 S$ were very sparse in public databases such as The Barcode of Life Data Systems (BOLD) or NCBI, we only used COII to estimate genetic distances between species and for phylogenetic tree inference. Inter-generic COII $p$-distances for available genera (Table 5) showed that Bifiditermes is closest to Proneotermes $(0.153$ SE 0.015). 
Table 3. Morphometrical measurements for $P$. macondianus sp. n. soldiers.

\begin{tabular}{c|l|c|c|c}
\hline No. & \multicolumn{1}{|c|}{ Measurements in $\mathbf{m m}(\mathbf{n}=\mathbf{1 1})}$. & Mean & SD & Range \\
\hline 1 & Head length to tip of mandibles & 2.75 & 0.11 & $2.50-2.95$ \\
\hline 2 & Head length to frontal horns & 1.72 & 0.10 & $1.54-1.90$ \\
\hline 3 & Frontal flange width & 1.03 & 0.04 & $0.92-1.08$ \\
\hline 4 & Genal horns outside span & 1.12 & 0.05 & $1.02-1.19$ \\
\hline 5 & Head width max. & 1.23 & 0.06 & $1.14-1.32$ \\
\hline 6 & Head height excluding postmentum & 0.99 & 0.06 & $0.85-1.08$ \\
\hline 7 & Pronotum max. width & 1.19 & 0.07 & $1.05-1.27$ \\
\hline 8 & Pronotum max. length & 0.82 & 0.05 & $0.73-0.87$ \\
\hline 9 & Left mandible length, tip to ventral condyle $(\mathrm{n}=1)$ & 1.10 & - & - \\
\hline 10 & Total length & 6.57 & 0.44 & $5.43-6.98$ \\
\hline 11 & No. antennal articulations & 11 & 0.7 & $10-12$ \\
\hline
\end{tabular}

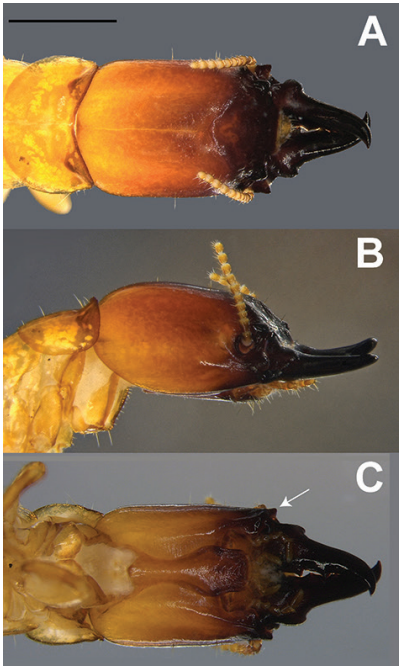

$\mathbf{A}$
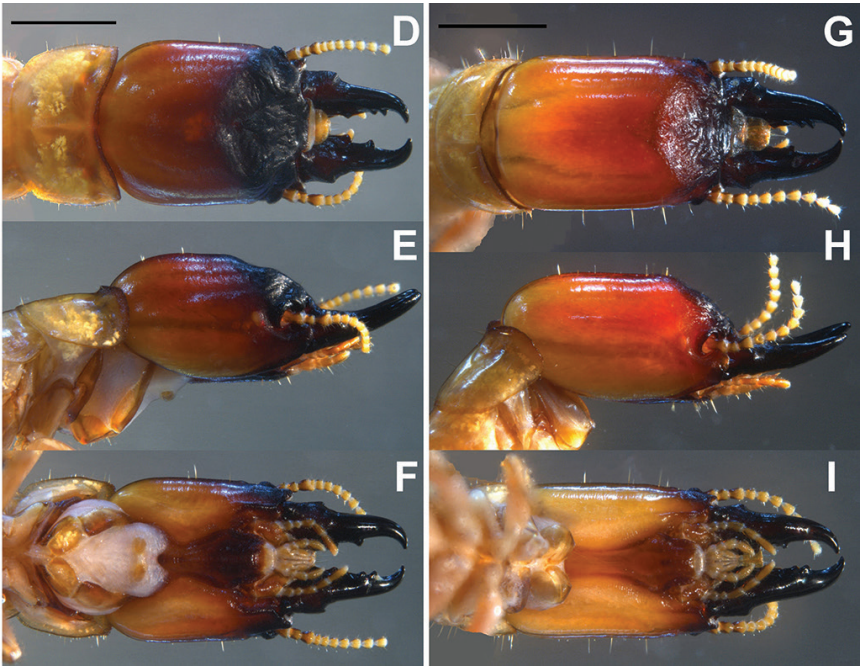

Figure 4. Soldier heads of Proneotermes macondianus sp. n. (A-C), Proneotermes latifrons (D-F), Proneotermes perezi $(\mathbf{G}-\mathbf{I})$. Head in dorsal $(\mathbf{A}, \mathbf{D}, \mathbf{G})$, lateral $(\mathbf{B}, \mathbf{E}, \mathbf{H})$ and ventral position $(\mathbf{C}, \mathbf{F}, \mathbf{I})$. Arrow in $4 \mathrm{C}$ denote genal horn projected prominently in Proneotermes macondianus sp. $\mathrm{n}$. Scale bars: $1 \mathrm{~mm}$.

Ecological notes. Proneotermes macondianus sp. $\mathrm{n}$ was found in tropical dry forests of the Colombian Caribbean near to coastal areas up to $25 \mathrm{~km}$ inland (Fig. 1, Appendix 1 - Figure S1). Encounters of Proneotermes were scarce. In line transects that covered a total area of $1500 \mathrm{~m} \times 2 \mathrm{~m}$, only $0.82 \%$ of all termite samples $(\mathrm{n}=1102)$ were $P$. macondianus $(\mathrm{n}=9)$. All samples were from thin pieces of drywood branches: less than $2 \mathrm{~cm}$ diameter on the ground, with a maximum of 20 individuals per branch. Pellets were hexagonal in shape, beige in colour and had a length of $0.92+/-0.04 \mathrm{~mm}$ (Appendix 1: Figure S1, S2, Table S1). It was impossible to identify the plant species from the small dry branches where $P$. macondianus sp. n. was found. 
Table 4. Nucleotide distances for combined analysis of COII, $12 \mathrm{~S}$ rDNA and $16 \mathrm{~S}$ rDNA genes between localities of $P$. macondianus sp. n. ( $p$-distance). Standard error estimates are shown above the diagonal.

\begin{tabular}{c|l|c|c|c|c}
\hline No. & Species $(\mathbf{n}=$ number of sequenced specimens) & Localities & CE & CO & PT \\
\hline 1 & Proneotermes macondianus $\mathrm{n}=1$ & CE & & 0.002 & 0.004 \\
\hline 2 & Proneotermes macondianus $\mathrm{n}=4$ & CO & 0.004 & & 0.004 \\
\hline 3 & Proneotermes macondianus $\mathrm{n}=1$ & PT & 0.024 & 0.025 & \\
\hline
\end{tabular}

Samples localites: CE = El Ceibal (Santa Catalina, Bolívar), CO = Los Primates (Colosó, Sucre), PT = Parque Tayrona (Santa Marta, Magdalena)

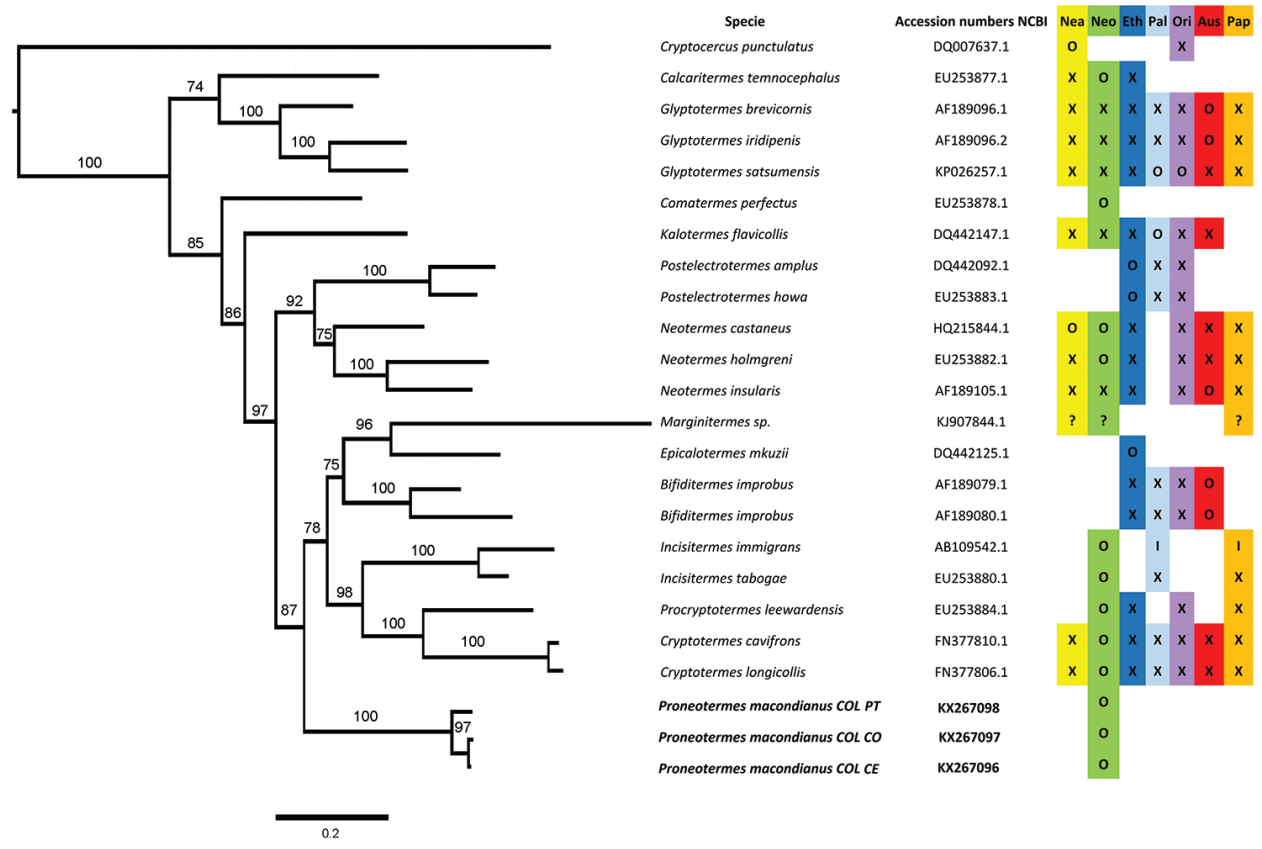

Figure 5. Bayesian inference tree, inferred with MRBAYES from COII sequence data (nodes show posterior probability support). Kalotermitidae distribution (X), Species distribution known (O), unknown (?) and established introductions from other regions (I). Neartic $=$ Nea, Neotropic $=$ Neo, Ethiopian $=$ Eth, Paleartic $=$ Pal, Oriental $=$ Ori, Australian $=$ Aus, Papuan $=$ Pap. Distribution based on Krishna et al. 2013.

Material examined. Holotype colony: Colombia: Municipality of Santa Marta, Magdalena. Tayrona National Natural Park, Gairaca Bay: $11.3152^{\circ} \mathrm{N}, 74.1032^{\circ} \mathrm{W}$ (Fig. 1), 6m, 27.VI.15 by R. Casalla. COLPT4K1-206. Holotype: Soldier, paratypes: 5 soldiers, 2 reproductives, and few pseudergates, two used for DNA analysis. Municipality of Santa Catalina, Bolívar. Protected area "El Ceibal": $10.6336^{\circ} \mathrm{N}, 75.2517^{\circ} \mathrm{W}$, 25m, 30.VIII.14 R. Casalla. COLCE3F5-155, COLCE3G5-158, COLCE3H2-160: Paratypes: 4 soldiers, 5 functional reproductives, and few pseudergates, two used for DNA analysis. Municipality of Colosó, Sucre. Serranía de Coraza y Montes de María. 


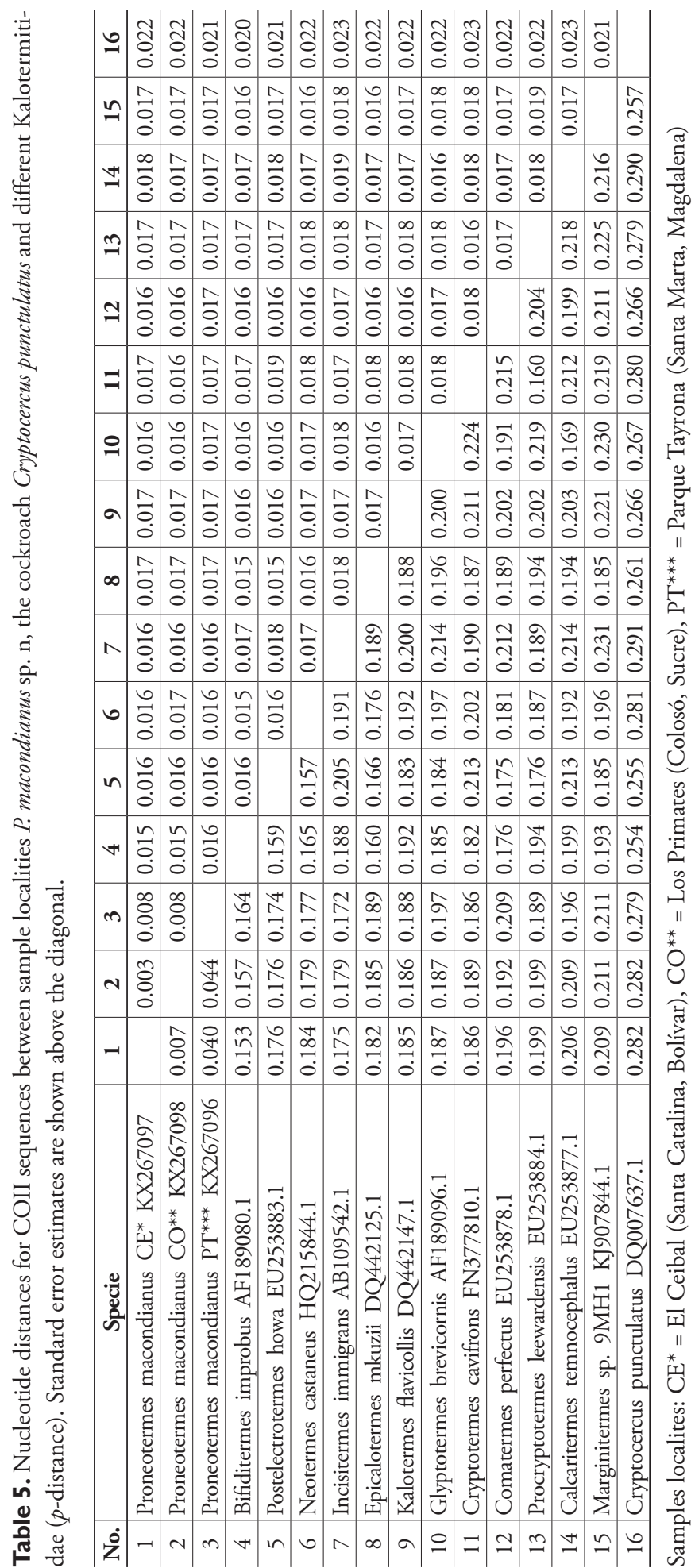


Protected área "Los Primates": 9.5332 N, 75.3479W, 223m, 27.VII.14 R. Casalla. COLCO4F4-226: Paratypes: 1 soldier, 1 winged imago, 2 dealated imagoes, one used for DNA analysis. Measurements for holoype, paratype soldiers and imagoes are reported in Table 2 and 3. The holotype and clearly colored paratype soldiers from COLCE3F5-155 will be deposited in the Arthropod Collection of the Natural History Museum of the Alexander von Humboldt Institute of Bogotá, Colombia (MIAvH). A paratype soldier from holotype colony, will be deposited in the American Museum of Natural History, New York, United States. Morphotype imagoes, paratype soldiers and pseudergates will be part of the collection of the Department of Chemistry and Biology at the University del Norte, Barranquilla, Colombia.

Etymology. Macondianus: In honour of Nobel laureate Gabriel García Marquez and the fictional town "Macondo" in his novel "One hundred years of solitude". "Macondiano/a" is also a Spanish world used in Colombia to describe an incredible, rare or surprising event that could only be compared with the fictional universe and magical realism of this novel.

\section{Redescription of Proneotermes latifrons}

Silvestri's $(1901,1903)$ descriptions of the P. latifrons soldier are incomplete. Some characters such as frons angle, horns, and postmentum morphology were not included. Also morphometrical measurements are incomplete. Herein, we included morphometrical measurements for the soldier caste. The imago caste is unknown.

\section{Proneotermes latifrons (Silvestri, 1901)}

Material examined. Venezuela: Bolivar State, El Pauji: $4.4675^{\circ} \mathrm{N}, 61.5947^{\circ} \mathrm{W}, 600 \mathrm{~m}$, 25.VII.2003, J Perozo, University of Florida no. SA336: 2 soldiers and pseudergates. Falcon State, La Chapa: $11.2657^{\circ} \mathrm{N}, 69.6022^{\circ} \mathrm{W}, 703 \mathrm{~m}, 27 . \mathrm{V} .2008$, Scheffrahn et al., VZ833, 2 soldiers, pseudergates. Lara State, Copeyal: $10.4409^{\circ} \mathrm{N}, 69.4402^{\circ} \mathrm{W}, 590 \mathrm{~m}$, 28.V.2008, Scheffrahn et al., VZ1014, 10 soldiers, pseudergates. Yaracuy State, Licua: $10.3377^{\circ} \mathrm{N}, 69.1344^{\circ} \mathrm{W}, 650 \mathrm{~m}, 30 . \mathrm{V} .2008$, Scheffrahn et al., VZ1180-11183, 4 colonies, many soldiers, pseudergates.

Soldier (Fig. 4D-F, Table 6). Head in dorsal view with frons dark glossy until faint bridge, grading from ferruginous orange to orange-yellow toward vertex. Postclypeus whitish at borders. Mandibles black anteriorly and reddish brown at hump. Head in lateral view with dark ferruginous orange, then turns orange to genal region. Head in ventral view with postmentum chestnut-dark brown and whitish at anterior border and genal margin pale orange. Eye spots distinct, unpigmented. Pronotum hyaline with sclerotized borders. First three antennal segments darker.

Head subsquare with sides slightly convergent, posteriorly and rounded to vertex. Frontal area wide and long, occupies ca 2/5 of head length to postclypeus; narrowly depressed 
Table 6. Morphometrical measurements for soldiers of Proneotermes latifrons.

\begin{tabular}{c|l|c|c|c}
\hline No. & \multicolumn{1}{|c|}{ Measurements in mm $(\mathbf{n}=\mathbf{1 1})}$. & Mean & SD & Range \\
\hline 1 & Head length to tip of mandibles & 2.96 & 0.19 & $2.65-3.35$ \\
\hline 2 & Head length to frontal horns & 1.82 & 0.31 & $1.10-2.25$ \\
\hline 3 & Frontal flange width & 1.06 & 0.12 & $0.90-1.25$ \\
\hline 4 & Genal horns, outside span & 1.33 & 0.12 & $1.20-1.55$ \\
\hline 5 & Head width max. & 1.46 & 0.12 & $1.15-1.60$ \\
\hline 6 & Head height excluding postmentum & 1.17 & 0.14 & $1.00-1.50$ \\
\hline 7 & Pronotum max. width & 1.49 & 0.12 & $1.20-1.65$ \\
\hline 8 & Pronotum max. length & 0.82 & 0.09 & $0.70-0.95$ \\
\hline 9 & Left mandible length, tip to ventral condyle & 1.06 & 0.03 & $1.00-1.10$ \\
\hline 10 & Total length & 7.38 & 0.61 & $6.80-8.80$ \\
\hline 11 & No. antennal articulations & 11 & 0.7 & $10-12$ \\
\hline
\end{tabular}

in center, and laterally view with faintly convex and few undulations, sloping angle ca. $50^{\circ}$ near to postclypeus. Labrum short and sub-squared. Antennal socket protruded with third antennal segment longer and sclerotized, formula $2<3>4=5=6$ and 11 articulations. Postmentum very broad in front. Pronotum as broad as head with anterior emarginated. Mandibles strong and curved inward ca. $45-50^{\circ}$. Measurements are reported in Table 6.

Comparisons. Soldiers of $P$. latifrons are separated from congeners in having a wide and darker convex frons with narrow undulations dorso-laterally. Postclypeus whitish at border, labrum wider than long and darker postmentum. P. latifrons is distributed in Venezuela, while $P$. perezi is widely distributed in Central America, from Guatemala to Panama (Fig. 1).

\section{Additional descriptions for Proneotermes perezi}

Material examined. Guatemala: San Jose La Arada: $14.6965^{\circ} \mathrm{N}, 89.6255^{\circ} \mathrm{W}, 992 \mathrm{~m}$, 3.VI.2006, Scheffrahn et al., GUA768-769, 2 colonies many soldiers, pseudergates3 alates. Ipala: $14.5992^{\circ} \mathrm{N}, 89.6411^{\circ} \mathrm{W}, 873 \mathrm{~m}, 3$. VI.2006, Scheffrahn et al., GUA793, 5 pseudergates $6 \mathrm{~km} \mathrm{NW}$ Jutiapa: $14.3307^{\circ} \mathrm{N}, 89.8622^{\circ} \mathrm{W}, 964 \mathrm{~m}, 3 . V I .2006$, Scheffrahn et et al., GUA822-824, 3 colonies 3 soldiers, many pseudergates, many alates. San José Acatempa: $14.2537^{\circ} \mathrm{N}, 90.1259^{\circ} \mathrm{W}, 1277 \mathrm{~m}$ 3.VI.2006, Scheffrahn et al., GUA845-851, 7 colonies many soldiers, pseudergates, 4 alates. Honduras: P. N. Capiro summit: $15.8697^{\circ} \mathrm{N}, 85.9564^{\circ} \mathrm{W}, 942 \mathrm{~m}, 29 . V .2007$, Scheffrahn et al., HN217, 5 soldiers, many pseudergates. Amarateca: $14.2247^{\circ} \mathrm{N}, 87.3765^{\circ} \mathrm{W}, 991 \mathrm{~m}, 2 . V I .2007$, Scheffrahn et et al., HN693, 1 soldier, many pseudergates. Panama: Gamboa: $9.12^{\circ} \mathrm{N}$, $79.70^{\circ} \mathrm{W}, 9 . V I .2005$, W. Reeves, University of Florida no. CTA48, 2 alates after rain. Valle de las Minas: $8.6369^{\circ} \mathrm{N}, 82.2114^{\circ} \mathrm{W}, 1050 \mathrm{~m}$, Scheffrahn et al., 1.VI.2010, PN1166-1167, 2 colonies many soldiers, pseudergates. 
Table 7. Morphometrical measurements for soldiers of Proneotermes perezi.

\begin{tabular}{c|l|c|c|c}
\hline No. & \multicolumn{1}{|c|}{ Measurements in mm $(\mathbf{n}=\mathbf{1 0})}$. & Mean & SD & Range \\
\hline 1 & Head length to tip of mandibles & 3.36 & 0.23 & $3.05-3.80$ \\
\hline 2 & Head length to frontal horns & 2.23 & 0.09 & $2.10-2.35$ \\
\hline 3 & Frontal flange width & 0.93 & 0.11 & $0.75-1.10$ \\
\hline 4 & Genal horns outside span & 1.41 & 0.11 & $1.20-1.60$ \\
\hline 5 & Head width max. & 1.52 & 0.09 & $1.30-1.65$ \\
\hline 6 & Head height excluding postmentum & 1.24 & 0.08 & $1.10-1.40$ \\
\hline 7 & Pronotum max. width & 1.46 & 0.13 & $1.20-1.55$ \\
\hline 8 & Pronotum max. length & 0.90 & 0.08 & $0.80-1.00$ \\
\hline 9 & Left mandible length, tip to ventral condyle & 1.28 & 0.08 & $1.15-1.40$ \\
\hline 10 & Total length & 7.88 & 0.60 & $7.00-8.80$ \\
\hline 11 & No. antennal articulations & 12 & 0.9 & $11-14$ \\
\hline
\end{tabular}

\section{Proneotermes perezi (Holmgren, 1911)}

Krishna (1961) described alates and soldiers of $P$. perezi but did not include measurements. Herein, we report measurements of the soldier, along with new locations and images (Figs 1, 4G-I, Table 7).

\section{Genus Proneotermes Holmgren, 1911}

Redescription. Soldiers with head robust, dark coloration in frons, nearly black, grading from ferruginous orange to orange-yellow toward vertex. Frons sloping between $43-50^{\circ}$ to postclypeus, without a ridge and vestigial rugosity. Mandibles bended upwards, with a strong dentition and left mandible bigger than right. Mandibular humps pronounced. Eyes spot unpigmented. Third antennal article larger than second and fourth and sclerotized. Pronotum almost as broad as head width. Femur tick, short and strong. Tibal spurs 3:3:3.

Based on our measurements and morphological description, we developed an identification key for the three Proneotermes species

\section{Key to the species Proneotermes based on soldier caste}

1 Smaller species; maximum head width 1.14-1.32 mm (mean 1.23 SD 0.06 $\mathrm{mm}$ ). Lateral margins of the genal horns angle outward from the sides of the head capsule (Fig. 4A, C) ..................................P. macondianus sp. $n$

- $\quad$ Larger species; maximum head width1.15-1.65 mm (mean 1.49 SD 0.11 $\mathrm{mm}$ ); lateral margins of the genal horns remain in line with the head capsule (Figs 4F, I) 
2 In lateral view; frons forms even curve below vertex and mandibles (Fig. 4E); postmentum about twice as long as wide. Posterior margin conical (Fig. 4F) ...

P. latifrons

- In lateral view; frons forms rather straight angle from vertex to mandibles (Fig. $4 \mathrm{H}$ ); postmentum about three fifths as long as wide. Posterior margin convex (Fig. 4I)

P. perezi

\section{Discussion}

The phylogenetic relationships within the Kalotermitidae are not clearly resolved yet. Krishna (1961) hypothesized that, based on wing venation and morphology of imago mandibles, Proneotermes is sister group to a clade composed of Tauritermes, Allotermes, Mariginitermes, and Incisitermes. In contrast, our phylogenetic tree shows Proneotermes, a Neotropical group, is monophyletic (87\% BPP), separated from ancestral line of those who originated Marginitermes and the Old World genus Bifiditermes, Epicalotermes, and New World Incisitermes and the Pantropical Cryptotermes. However, our results suggest that the genetic distances between Proneotermes and congeners are quite high ( $p$-distance $0.153-0.211$ for COII fragment) and the closest genus to Proneotermes is Bifiditermes (Table 4).

Using a single mitochondrial marker (COII) available for 12 Kalotermitidae genera, our results resemble those from Legendre et al. (2008), who included seven gene fragments in combination with morphological characters in their analyses. To fully resolve phylogenetic relationships within the cosmopolitan Kalotermitidae, a denser taxon sampling along with covering more genetic markers, ideally including nuclear loci and moreover morphological characters is needed.

\section{Acknowledgments}

We thank Universidad del Norte Barranquilla, Colombia, for a research grant to R.C. as part of the Strategic Research Area in Biodiversity, Ecosystem Services and Human Well-being Program, as well as the University of Freiburg, Germany, and COLCIENCIAS-Colfuturo for financial support. We are also grateful to the National Agency of Environmental Licenses for research permit no. 739/ANLA/MADS (8 July 2014) and the Natural Parks Unit research permit 005/PNNC/ANLA/MADS (10 July 2015). Thanks to Miss Sandra Cabarcas for hospitality and the possibility to access the homestead "El Ceibal", to the field assistants Luis Fernando Lopez and Saudy Royero. Thanks to Karen Meusemann for comments on the text and all those who indirectly helped in conducting this work and the two referees for their constructive comments on the manuscript. 


\section{References}

Bourguignon T, Lo N, Cameron SL, Šobotník J, Hayashi Y, Shigenobu S, Watanabe D, Roisin Y, Miura T, Evans TA (2014) The evolutionary history of termites as inferred from 66 mitochondrial genomes. Molecular Biology and Evolution 32: 406-421. doi: 10.1093/ $\mathrm{molbev} / \mathrm{msu} 308$

Casalla R, Scheffrahn R, Korb J (2016) Cryptotermes colombianus a new drywood termite and distribution record of Cryptotermes in Colombia. ZooKeys 596: 39-52. doi: 10.3897/ zookeys.596.9080

Doyle J, Doyle JL (1987) A rapid DNA isolation procedure for small quantities of fresh leaf tissue. Phytochemistry Bulletin 19: 11-15.

Froggatt W (1897) Australian Termitidae part II. Proceedings of the Linnean Society of New South Wales 21: 510-552. doi: 10.5962/bhl.part.8483

García Marquez G (1975) One hundred years of solitude. Plaza and Janés Editors, Barcelona, Spain, 383 pp.

Hausberger B, Kimpel D, Neer A, Korb J (2011) Uncovering cryptic species diversity of a termite community in a West African savanna. Molecular Phylogenetics and Evolution 61: 964-969. doi: 10.1016/j.ympev.2011.08.015

Hausberger B, Korb J (2015) A phylogenetic community approach for studying termite communities in a West African savannah. Biology Letters 11: 20150625. doi: 10.1098/rsbl.2015.0625

Holmgren N (1911) Termitenstudien II Systematik der Termiten. Die Familien Mastotermitidae, Protermitidae und Mesotermitidae. Kungliga Svenska Vetenskaps-Akademiens Handlingar 46(6): 1-88.

Instituto de Investigación Alexander von Humboldt (2014) Pizano C, García H (Eds) El Bosque Seco Tropical en Colombia. Bogotá, Colombia, 353 pp. http://www.humboldt.org. co/es/component/k2/item/529-el-bosque-seco-tropical-en-colombia

Inward D, Vogler A, Eggleton P (2007) A comprehensive phylogenetic analysis of termites (Isoptera) illuminates key aspects of their evolutionary biology. Molecular Phylogenetics and Evolution 44: 953-967. doi: 10.1016/j.ympev.2007.05.014

Jones DT, Eggleton P (2000) Sampling termite assemblages in tropical forests: testing a rapid biodiversity assessment protocol. Journal of Applied Ecology 37: 191-203. doi: 10.1046/j.1365-2664.2000.00464.x

Krishna K (1961) A generic revision and phylogenetic study of the family Kalotermitidae (Isoptera). Bulletin of the American Museum of Natural History 122: 303-408.

Krishna K, Grimaldi D, Krishna V, Engel M (2013) Treatise on the Isoptera of the world. Bulletin of the American Museum of Natural History 377: 1-2704. doi: 10.1206/377.1

Kumar S, Stecher G, Tamura K (2016) MEGA7: Molecular Evolutionary Genetics Analysis version 7.0 for bigger datasets. Molecular Biology and Evolution 33: 1870-1874. doi: $10.1093 / \mathrm{molbev} / \mathrm{msw} 054$

Legendre F, Whiting M, Bordereau C, Cancello E, Evans T, Grandcolas P (2008) The phylogeny of termites (Dictyoptera: Isoptera) based on mitochondrial and nuclear markers: Implications for the evolution of the worker and pseudergate castes, and foraging behaviors. Molecular Phylogenetics and Evolution 48: 615-627. doi: 10.1016/j.ympev.2008.04.017 
Morrone J (2006) Biogeographic areas and transition zones of Latin America and the Caribbean islands based on panbiogeographic and cladistic analyses of the entomofauna. Annual Review of Entomology 51: 467-494. doi: 10.1146/annurev.ento.50.071803.130447

Robledo G, Giorgio E, Franco C, Popoff O, Decock C (2014) Gyrodontium sacchari (Spreng.: Fr.) Hjortstam (Boletales, Basidiomycota) in America: new records and its geographic distribution. Check List 10: 1514-1519. doi: 10.15560/10.6.1514

Rodríguez M, Chacón de Ulloa P, Abadía J (2012) Presencia de Incisitermes cf. schwarzi (Kalotermitidae) en zona urbana del Pacífico colombiano. Boletín del Museo de Entomología de la Universidad del Valle 12: 29-31.

Ronquist F, Huelsenbeck JP (2003) MrBayes 3: Bayesian phylogenetic inference under mixed models. Bioinformatics 19: 1572-1574. doi: 10.1093/bioinformatics/btg180

Roonwal M (1969) Measurement of termites (Isoptera) for taxonomic purposes. Journal of the Zoological Society of India 21: 9-66.

Silvestri F (1901) Nota preliminare sui Termitidi sud-americani. Bollettino dei Musei di Zoologia ed Anatomia Comparata della Reale Università di Torino 16: 1-8.

Silvestri F (1903) Contribuzione alla conoscenza dei termite e termitofili dell'America meridionale. Redia 1: 1-234.

Thompson GJ, Miller LR, Lenz M, Crozier RH (2000) Phylogenetic analysis and trait evolution in Australian lineages of drywood termites (Isoptera, Kalotermitidae). Molecular Phylogenetics and Evolution 17: 419-429. doi: 10.1006/mpev.2000.0852

Vargas-Niño A, Sánchez-Múñoz O, Serna-Cardona D (2005) Lista de los géneros de Termitidae (Insecta: Isoptera) de Colombia. Biota Colombiana 6: 181-190. 


\section{Appendix I}

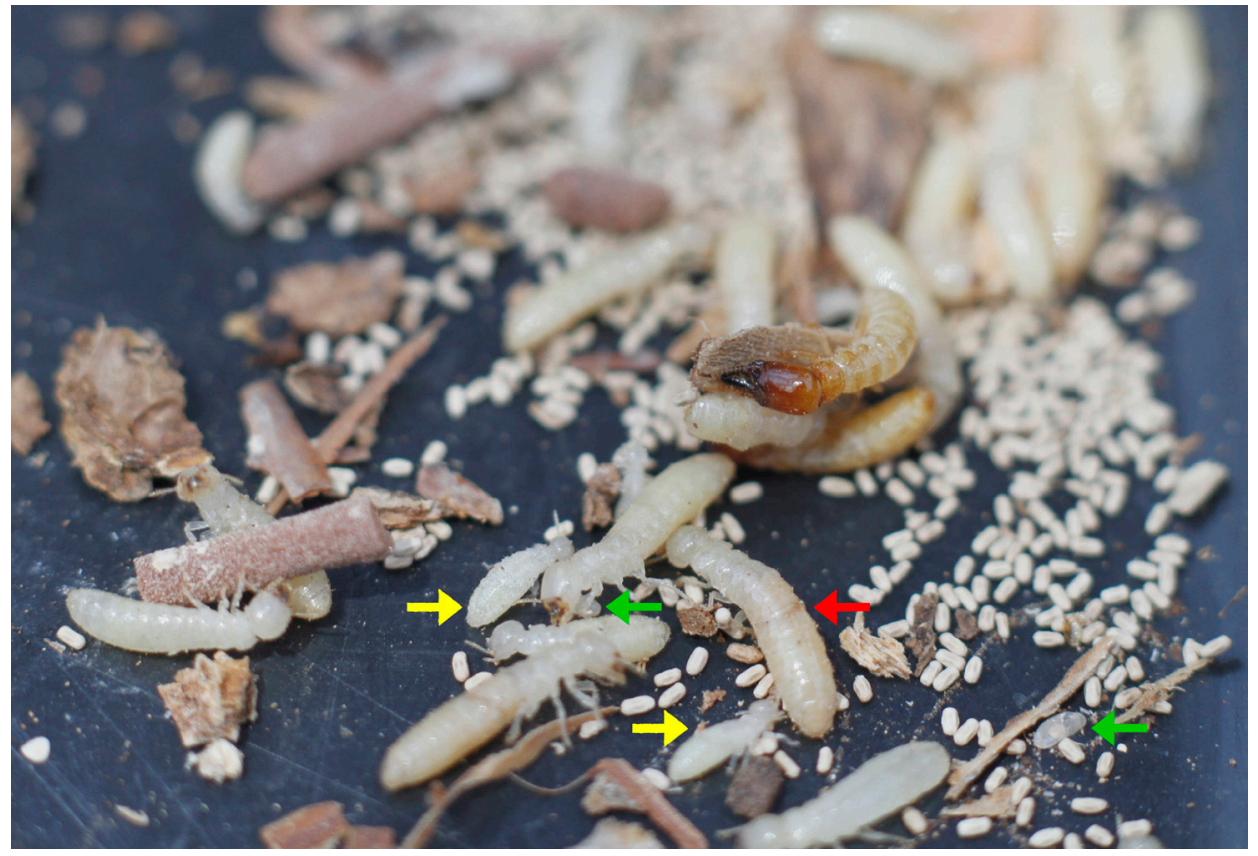

Figure SI. Macrophotography of $P$. macondianus sp. n. alive from National Park Tayrona. Santa Marta. Magdalena Colombia. Two soldiers (one partly hidden), some pseudergates (whitish, red arrow), two larva (yellow arrow), two eggs (green arrow), and some dry pellets.

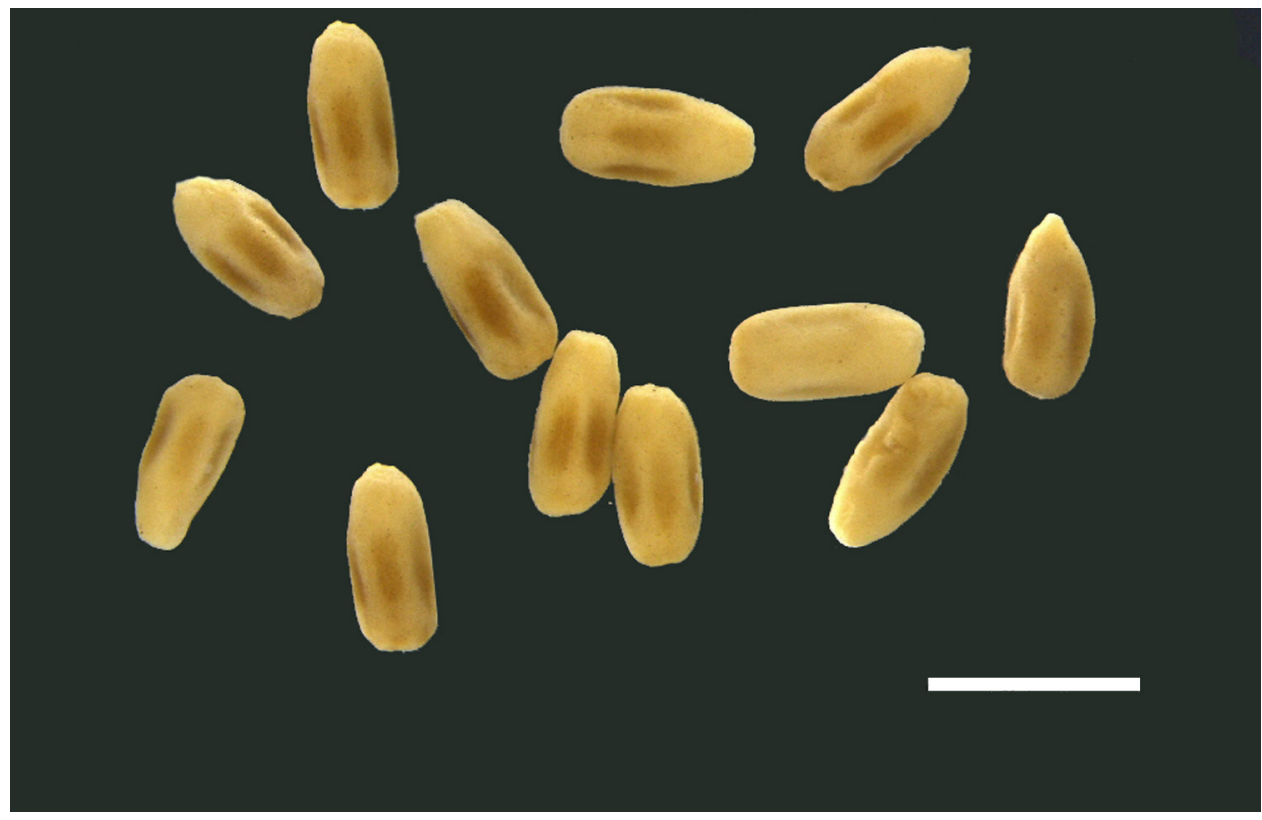

Figure S2. Dry pellets of $P$. macondianus sp. n. Scale bar $1 \mathrm{~mm}$. 
Table SI. Size of pellet of P. macondianus sp. n.

\begin{tabular}{c|c}
\hline Pellet & Length $(\mathbf{m m})$ \\
\hline 1 & 0.92 \\
\hline 2 & 0.86 \\
\hline 3 & 0.92 \\
\hline 4 & 0.91 \\
\hline 5 & 0.96 \\
\hline 6 & 0.96 \\
\hline 7 & 0.91 \\
\hline 8 & 0.97 \\
\hline 9 & 0.95 \\
\hline 10 & 0.87 \\
\hline 11 & 0.9 \\
\hline Mean & $\mathbf{0 . 9 2}$ \\
\hline SD & $\mathbf{0 . 0 4}$ \\
\hline
\end{tabular}

